https://doi.org/10.4316/CC.2020.02.003

\title{
SOCIETAL PERSPECTIVES: GENDER EQUALITY IN CENTRAL ASIA, BETWEEN DESIDERATUM AND REALITIES
}

\author{
Roza ZHARKYNBAYEVA ${ }^{1}$ iD , Ardak ABDIRAIYMOVA ${ }^{2}$ iD), \\ Akylbek SARSENBAYEV ${ }^{2}$ iD , Nurgul' BEKZHANOVA ${ }^{1}$ \\ ${ }^{1}$ Al-Farabi Kazakh National University \\ 2 M. Tynyshpaev Kazakh Academy of Transports \& Communications \\ E-mails: Roza.zharkynbayeva@gmail.com; ardak.abdiraiymova@gmail.com; \\ a.sarsenbayev@kazatk.kz; nurgul.b.98@mail.ru
}

\begin{abstract}
During the years of independence, Central Asian countries joined the Convention on the Elimination of all Forms of Discrimination against Women (CEDAW). They developed national mechanisms for the promotion of gender equality. However, despite the claimed policy, numerous articles, studies, dissertations, conferences, round tables, and the creation of gender research centres, there are still significant problems in promoting an idea of gender equality. In the Central Asia region persist a substantial difference between men and women in such spheres as politics, economics and public services careers. Gender inequality is still present in political representation. In addition, there is a problem of female students underrepresented in higher education institutions in several countries of the Central Asian region (Uzbekistan, Tajikistan, and Turkmenistan). Moreover, the traditionalization of the social dimension of life in these societies is becoming more pronounced. Under the guise of the policy of preserving national customs, the constraints imposed by traditional rites extend.

However, the politics of promotion of gender equality have perspectives for development since the governments are interested in this issue management. Instead, the traditional part of society shows a particular resistance to the ideology of gender equality. Nevertheless, sustainable socio-economic development of the region is impossible without the achievement of gender equality.
\end{abstract}

Keywords: Gender equality, sustainable development, modernization, higher education, employment opportunities, cooperation, professional gender segregation.

Rezumat: Perspective societale: egalitatea de gen în Asia Centrală, între deziderate și realități. După obținerea independenței, țările din Asia Centrală s-au alăturat Conventiei privind eliminarea tuturor formelor de discriminare împotriva femeilor (CEDAW) și au dezvoltat mecanisme naționale pentru promovarea egalității de gen. Cu toate acestea, în ciuda 
politicii proclamate, a unui număr impresionant de articole, studii, teze, conferințe, mese rotunde și a creării unor centre de cercetare a problemelor de gen, există încă dificultăți în susținerea ideii egalității de gen. În regiunea Asiei Centrale persistă diferențe semnificative între bărbați și femei în domenii precum politica, economia și cariera în serviciile publice. Inegalitatea de gen apare și la nivel politic. În plus, există o problemă de subreprezentare a femeilorstudente în instituțiile de învățământ superior din mai multe țări aparținând regiunii Asiei Centrale (Uzbekistan, Tadjikistan, Turkmenistan). Mai mult, tradiționalizarea dimensiunii sociale a vieții devine tot mai pronunțată în aceste state. Sub paravanul politicii de prezervare a obiceiurilor naționale se extind constrângerile impuse de riturile tradiționale.

Totuși, politica de promovare a egalității de gen are perspective de dezvoltare, întrucât guvernele sunt interesate de gestionarea acestei probleme. În schimb, segmentul tradiționalist al societății manifestă o rezistență deosebită la ideologia egalității de gen. Cu toate acestea, dezvoltarea socio-economică durabilă a regiunii este imposibilă fără realizarea egalităţii de gen.

\section{INTRODUCTION}

Globalization has brought new opportunities for development and new challenges and threats for Central Asian (CA) region. Significant concerns are caused by the negative impact of existing problems in the area, especially the risk of economic lagging, transformation into raw materials providers for the developed countries, decreasing living standards, decreasing education level, and lack of technological progress. The most actual problems are "brain drain", social polarization of society and gender inequality.

There is a strong correlation between sustainable development and gender equality. Sustainable development implies the satisfaction of current needs without threatening future generations' ability to satisfy their own needs. All memberstates of the United Nations, including the CA region countries, joined UN sustainable development goals in September 2015. Here, 12 out of 17 goals are gendersensitive. Consequently, gender equality has become an essential issue for all countries in the CA region.

During the years of independence, all Central Asian countries joined the Convention on the Elimination of all Forms of Discrimination against Women (CEDAW): Tajikistan joined in 1993, Uzbekistan in 1995, Kyrgyzstan and Turkmenistan in 1996 and Kazakhstan in 1998. Later, these countries' governments developed national mechanisms for the promotion of gender equality. Consequently, there were attempts to reinforce gender equality in the region. For instance, Kyrgyzstan was the first post-soviet country that adopted “Об основах 
государственных гарантий обеспечения гендерного равенства в Кыргызской Республике"1 law in 2003. The new version of the law, "О государственных гарантиях равных прав и равных возможностей для мужчин и женщин” 2 was adopted in 2008. Tajik government adopted “О государственных гарантиях равноправия мужчин и женщин и равных возможностях их реализации" 3 law in 2004. Kazakhstan in its turn has adopted two main laws with regard to gender: “О государственных гарантиях равных прав и равных возможностей мужчин и женщин"4 and “О профилактике бытового насилия"5 in 2009. Turkmenistan adopted “О государственных гарантиях обеспечения равных прав и равных возможностей женщин и мужчин"6 law in 2015. Some countries of the region introduced quotas for promotion of women into the political sphere. For example, a 30\% quota for women in parliament was introduced in Uzbekistan (2003) and Kyrgyzstan (2007). Nevertheless, the CA region still faces the problem of significant difference in positions between men and women in political, economic, cultural and social spheres.

Achievement of gender equality is a pressing issue for the worldwide society as a whole. However, gender issues of the CA region countries are strikingly different from those in other parts of the world. Despite the claimed policy, numerous articles, monographs, dissertations, a significant number of conferences, round tables, and the creation of the centres of gender research, there are still significant problems in promoting an idea of gender equality. Also, society itself shows some resistance to the ideology of gender equality. The term "gender" has never been fully understood by society, but political institutions, and even scientific communities of the region. For the most part, the term was strongly associated with the word "woman". Gender aspects of inequality were considered relatable only to women.

In the Soviet Union (USSR), women of Central Asia and Kazakhstan had broad access to professional-technical education and represented a significant share of society's employed part. At the same time, women did not have adequate

${ }^{1}$ On the basics of state guarantees for gender equality in the Kyrgyz Republic.

${ }^{2}$ On the state guarantees of equal rights and equal opportunities for men and women.

${ }^{3}$ On the state guarantees of equality between men and women and equal opportunities for their implementation.

${ }^{4}$ On the state guarantees of equal rights and equal opportunities for men and women.

${ }^{5}$ On the prevention of domestic violence.

${ }^{6}$ On the state guarantees of ensuring equal rights and equal opportunities for women and men. 
access to governing processes and resources. An unwritten rule of the Soviet regime was "culture management" by women. ${ }^{7}$ Besides, the implementation of the ideological principles was managed by women, who usually were nominated for the communist party third secretary's post. The guiding principle of an active industrialization, urbanization and scientific and technical revolution during the Soviet modernization was the equality of men and women in economic and social spheres. At the same time, women still had to carry out their roles as housewives and mothers. This is evident because there was strong support for women in maternity leaves and taxes for having no children ${ }^{8}$. Women committees addressed women's issues, and some laws were adopted regarding the provision of equality between men and women in educational and professional spheres. Women represented the majority of jobs like teachers, doctors and engineers.

\section{RETRADITIONALIZATION OF SOCIAL LIFE}

The year 2020 marks the 25th anniversary since the Beijing Declaration and Platform for Action (Beijing +25) representing a comprehensive plan for worldwide gender equality provision. On the 6th March, United Nations Development Program (UNDP) proposed The Gender-Social Norms Index (GSNI), which allows measuring the extent to which existing social prejudices and stereotypes interfere with women achieving success in politics, on the labour market and education. Seventy-five countries were analysed, based on the Index with the global population coverage of $80 \%$. It was discovered that $96 \%$ of Kazakhstani population have prejudices against women. ${ }^{9}$

In general, Central Asian countries and Kazakhstan succeeded in the improvement of the status of women. During the $20^{\text {th }}$ century, the nations of Central Asia experienced dramatic changes, which changed the traditional woman's life. One of the most important events of the 1920s was Hujum - attacking old traditions and emancipation of women. Local women were exempted from an obligation to wear

7 Г. А. Хасанова, Гендер, политика, демократия [Gender, politics, democracy], Алматы, Институт Развития Казахстана, 2002, с. 14.

8 J. Cleuziou, L. Direnberger, Gender and nation in post-Soviet Central Asia: from national narratives to women's practices, in "Nationalities Papers", 2016, Vol. 44, No. 2, p. 195-206.

${ }_{9}^{9}$ В Казахстане 96\% населения имеют предрассудки в отношении женщин [90\% of Kazakhstani population believes in stereotypes about women]. https://www.kz.undp.org/content/kazakhstan/ru/home/presscenter/announcements/2020/march/in-kazakhstan-96-per-cent-of-population-are-biased-againstwomen.html (Accessed on February 13 ${ }^{\text {th }}$, 2020). 
paranja - traditional cover (similar to the burqa). For this important event, some women paid with their lives. Only during this period, women understood that they could participate in the country's social production and social-political life. On the one hand, Hujum was a part of the Soviet political intentions regarding the modernization of the region. On the other hand, re-traditionalization of social life in the post-Soviet Central Asia is a victory of patriarchal and fundamental foundations, expressed in an increased number of women wearing paranja.

Krumm mentioned the following: "In the east woman is dashing between contemporary reality and traditions. In this context, the government's task is to create such conditions so that a woman has the right to choose. This is not an assessment of what is good and what is bad. It is a search for how a woman can voluntarily choose her place in society." 10 The roots of social life re-traditionalization are lying in the historical past of society. Even though during the years of early Soviet modernization the laws against crimes on "remnants of family life" were adopted, these crimes did not disappear decisively. As a French researcher Habiba Fathi - stated: "The post-Hujum generation, which had to represent a perfect ideal of woman free from prejudices, is actually faithful to its traditional values, which were saved during repression years as an inevitable part of life."11 In turn, Saktaganova argued that pressure of ideology and repressive measures cultivated a "sacrifice syndrome" among Soviet women, which strengthened during the war period. ${ }^{12}$

In the Russian State Archive of Social-Political History, there is a memo by O. Mishakova, the Secretary of the Central Committee of VLKSM, ${ }^{13}$ to the Secretaries of the Central Committee of the All-Union Communist Party (Bolsheviks) "about the revival of remnants of the feudal-bai attitude towards women in the Uzbek, Turkmen and Tajik SSR" dated from 11th January 1946. This memo states that "there are facts of reviving feudal-bai attitude towards women in all republics

${ }^{10}$ R. A. Ubaydullaeva, R. Krumm (eds.), Women of independent Uzbekistan: findings of sociological survey, Center for the Study of Public Opinion "Izhtimoy Fikr", Friedrich Ebert Foundation, Tashkent, 2004, p. 156-157.

11 М. Тохтаходжаева, Утомленные прошлым. Реисламизация общества и положение женщин в Узбекистане [Exhausted by the past. Reislamization of society and status of women in Uzbekistan], Ташкент, 2001, с. 164.

12 Z. Saktaganova, K. Abdrakhmanov, S. Yeleukhanova, B. Dosova, Z. Karsybayeva, K. Tleugabylova, Women's labour and everyday life in the great patriotic war years, in “Opción”, Año 36, 2020, Especial No.27, pp. 1168-1183.

13 All-Union Leninist Young Communist League - a political youth organization in the Soviet Union. 
of Central Asia". Many women were wearing paranja, including young women with higher education, teachers and agronomists. The plurality was widespread; there were many facts of infanticide, abortions, and suicides of women. For example, there were 64 cases of women's self-immolation in a Mary region of Turkmenia during 1944-1945. When in the kolkhoz named after Voroshilov a young woman did an act of self-immolation, local party organization decided that "selfimmolation should be counted as a voluntary act, without other kolkhoznik's fault and to judge no one". Consequently, the commission found that kolkhoz farm chair, forced this girl cohabit and forced her to leave when she got pregnant. One more tragic occasion happened in the same kolkhoz when 13 years old girl "doused herself with kerosene and burned herself in the stove" when she knew that her parents decided she would marry an old man. The teacher from the Kara - Yab village also committed suicide due to systematic beatings and mockery of her husband. 0. Mishakova described these cases of suicide as a passive resistance, which turned out to be acts of self-immolation. There also were cases of women suicide due to domestic violence in Uzbekistan and Tajikistan. ${ }^{14}$ O. Mishakova was not a sentimental and soft person, but she was so struck by these cases that she raised these questions with the higher party management: I. V. Stalin, G. M. Malenkov, A. A. Zhdanov.

There are different opinions proposed by regional researchers, which give much attention to these problems. According to Kyrgyz anthropologist A. Kochkunov, the post-Soviet period revealed that ethnocultural traditions with a long history survived throughout the time, are likely to reborn under favourable conditions. These become socio-political, family-related, cultural and household development factors, also become a component of mentality and national-ethnic stereotype. ${ }^{15}$

Researchers from Uzbekistan state that traditionalization acquired hypertrophied forms; ritualism was reborn and was stimulated by religious apologetics.

${ }^{14}$ Докладная записка секретаря ЦК ВЛКСМ О. Мишаковой секретарям ЦК ВКП(Б) Сталину И. В., Маленкову Г. М., Жданову А.А. об оживлении пережитков феодально-байского отношения к женщине в Узбекской, Туркменской и Таджикской CCP [Memorandum by the secretary of the Komsomol Central Committee O. Mishakova to secretaries of the Central Committee of the CPSU(b) Stalin I. V., Malenkov G. M., Zhdanov A. A. about the revival of remnants of the feudal-bai perception of women in Uzbek, Turkmen and Tajik SSR], The Russian State Archive of Social and Political History (RGASPI), Fund M-1., 0. 4, D. 108, f. 22-29.

15 Айдарбек Кочкунов, Этнические традиции киргизского народа (социокультурные аспекты и некоторые вопросы генезиса) [Ethnic traditions of Kirgiz people (sociocultural aspects and some genesis issues)], Бишкек, 2013, с. 302. 
Rituals and ceremonies developed an increased connection with people's personal life and even labour activity. Simultaneously, the rise of traditionalism was an inhibiting factor and led to confessional isolation of dome parts of society. ${ }^{16}$ Over the last years, there is a tendency for local media to represent returning to the traditional value system. Such a trend, coupled with social instability, weak social institutes and unemployment is a way to disguise the reality of competition in the labour market and consequent reduction of the preschool system and not a revival of national identity during the post-Soviet period. ${ }^{17}$

Great attention is paid to preserving national and cultural traditions in the Central Asian region, especially those connected to the restriction of women's rights. For example, the Academy of Education of Tajikistan introduced gender education. Nevertheless, the head of the Academy stated the following: "Even if the stereotypes of the man and women could be erased, we should not forget about the mentality of Tajik people. It was developed throughout centuries, and we should not destroy all the good things it possesses. Some of the things are accepted in Europe, but not in Central Asia. In other words, some things should not be destroyed and should stay the same. Women should be feminine. And each woman should define her role at home". Noriko Igarashi and Kazuhiro Kumo consider that even if the Head of Academy working on the gender education program believes that Tajik traditions should be preserved or, in other words, that the gender situation would not change easily. ${ }^{18}$

Understanding the purpose of gender and gender norms is taught to children in Central Asia almost from the moment they are born. It means that parents communicate with their child differently based on gender. Parents lay on their children different aims and tasks, emphasizing differences and disregarding children's social behaviour and personality.

The unfolding developments in the post-Soviet countries can be examined in the context of so-called patriarchal pullback, a phenomenon of a ubiquitous nature. The retreat was linked to the men's fear regarding feminism and concerns about the possibility to lose their women, to possess less collective authority and

16 М. Тохтаходжаева, ор. cit., p. 27-28.

17 М. Эргашева, Время расцвета: деловая активность женщин как одна из составных частей дальнейшего развития Узбекистана [Time to unwind: business activity of women as one of the main parts of the development of Uzbekistan], Ташкент, Издательство Национальной библиотеки Узбекистана им. А. Навои, 2004, с. 19.

${ }^{18}$ Норико Игараси, Казухиро Кумо, Голоса женщин. Гендерное исследование в Таджикистане [Women's Voices: Gender Survey in Tajikistan], in "Japanese Slavic and East European Studies", 2016, Vol. 37, pp. 63-87. 
to allow women to have greater access to positions and roles previously owned by men exclusively. Moreover, this pullback is connected with a rise of religious and ethnic fundamental movements, which places control over women as a central issue of their symbolic social order ideologies. ${ }^{19}$

During the post-Soviet period, ideas of gender equality are perceived as the project of the Soviet regimen. Therefore, the renouncement of these ideas is a symbol of negation of the Soviet past.

The processes of rebuilding national identity intensified after the USSR collapsed. Here, appeal to "motherhood and 'traditional' femininity" was a significant part of local nationalism processes. ${ }^{20}$ Usually, this implies a hierarchy by gender and age, where women, especially younger ones, take a subordinate position, or the lowest place in this social scale. ${ }^{21}$ Also, politicians argued that liberating Soviet policies were destroying women's femininity, with most of the women agreeing with the argument. ${ }^{22}$ That is why it was important to revive femininity. One of the most important features was attributing femininity to a private or invisible space represented by the house and domestic duties. For example, according to Tajik society norms, men are usually the head of households, putting women in submissive and dependent position concerning decision-making and finance. ${ }^{23}$ Women also tend to justify violence from their husbands to themselves, which is also an indication of women obeying the tradition of putting their husbands in a dominant position. ${ }^{24}$ These all reinforced by the fact that, in general, the strongest national attributes are masculine. The significant figures from the past of a nation are usually men. The local objects are mostly defined by names of significant figures of men. ${ }^{25}$ In this way, during the post-Soviet period, some countries of the region enhanced discrimination norms against women in marital relations. Traditionally,

${ }^{19}$ Н. Юваль-Дэвис, Гендер и нация [Gender and Nation], Москва, ELPA, 2001, с. 196.

20 J. Cleuziou, L. Direnberger, Gender and nation..., p. 196.

21 Ibid.

22 Mary Buckley, Victims and agents: gender in post-Soviet states, in M. Buckley (ed.), PostSoviet Women: From the Baltic to Central Asia, Cambridge, Cambridge University Press, 1997, pp. 3-16.

23 Jane Falkingham, Angela Baskieri, Gender, poverty and transition in Central Asia, in Sylvia Chant (ed.), The International Handbook of Gender and Poverty. Concepts, Research, Policy, Cheltenham - Northampton, Edward Elgar Publishing, 2010, p. 186.

${ }^{24}$ Ibid.

25 N. Megoran, Theorizing gender, ethnicity and the nation-state in Central Asia, in "Central Asian Survey", 1999, Vol. 18, No. 1, pp. 99-110. 
women are considered to be fully prepared for motherhood and child-rearing earlier years, compared with men. For instance, in accordance with Article 15 of the Family Code of the Republic of Uzbekistan "брачный возраст устанавливается для мужчин в 18 лет, для женщин в 17 лет." 26 It is worth noting that "... при наличии уважительных причин, в исключительных случаях"27 it is possible to decrease marriageable age, but not more than by one year. ${ }^{28}$ Currently, Uzbekistan considers an opportunity to increase of marriageable age.

Following Article 13 of the Family Code of the Republic of Tajikistan (13th November 1998), the marriageable age for both males and females is 17 years. There also was an opportunity to decrease marriageable age, but again, "no more than by one year".29 Meanwhile, the norms of two international conventions ("Convention on the Elimination of all Forms of Discrimination against Women" and "Convention on the Rights of the Child") state that minors under age 18 are considered children. The January 2011 amendments to the Family Code of the Republic of Tajikistan changed marriageable age from 17 to 18 years. ${ }^{30}$ In Turkmenistan $^{31}$, Kyrgyzstan ${ }^{32}$ and Kazakhstan ${ }^{33}$ marriageable age is set to be 18 years. At the same time, it is possible to decrease marriageable age "не более, чем на один год". 34 The most significant control over the decrease of marriageable age is exercised in Kyrgyzstan based on the commission decision of territorial subunits of

26 "marriageable age is set to be 18 years for males and 17 years for females".

27 "in occasion of a valid excuse or exclusive event".

${ }^{28}$ Семейный Кодекс Республики Узбекистан, http://www.lex.uz/acts/104723 (Aсcessed on February 25 2 th 2020 ).

${ }^{29}$ Семейный Кодекс Республики Таджикистан (2006) [Family code of the Republic of Tajikistan], https://minjust.gov.ru/uploaded/files/5tadzhikistan.doc (Accessed on February $\left.25^{\text {th }}, 2020\right)$.

30 Семейный Кодекс Республики Таджикистан (2016) [Family code of the Republic of Tajikistan], http://www.afew.tj/images/files/pdf/semeynyy_kodeks_rt.pdf (Accessed on February $25^{\text {th }}, 2020$ ).

31 Семейный кодекс Туркменистана [Family code of Turkmenistan], http://www.turkmenbusiness.org/content/semeinyi-kodeks-turkmenistana (Accessed on February $\left.25^{\text {th }}, 2020\right)$.

32 Семейный кодекс Кыргызской республики [Family code of the Republic of Kyrgyzstan], http://www.ombudsman.kg/images/files/news/2018/za-

konodatelnayabaza/semejnij-kodeks-kg.doc (Accessed on February 25 ${ }^{\text {th }}, 2020$ ).

${ }_{33}$ Кодекс Республики Казахстан о браке (супружестве) и семье [Code of the Republic of Kazakhstan about marriage (matrimony) and family], https://online.zakon.kz/m/document/?doc_id=31102748 (Accessed on February 25 ${ }^{\text {th }}, 2020$ ).

34 "no more than by one year". 
authorized state bodies for the children's protection. In the event of its violation, that person will be responsible, according to the Kyrgyz Republic's legislation.

Particular importance is accorded to women's purity. Here, a sheet is checked after the wedding night to ensure a woman's innocence before the wedding. For this reason, women from conservative, traditional families have restricted freedom of movement. Cult of marriage and purity in Turkmen society started developing as well. Thus, "chastity" and a search for a virgin for marriage are central issues in current discussions among youth. ${ }^{35}$ Although some aspects of gender equality could be observed at the beginning of the 1990s, the conservative ideology has developed and expanded since the 2000s, supported by patriarchal traditions and religious institutions.

An increased influence of religion in the post-soviet region contributed to the increasing pressure on women. It also reinforced females to have a subordinate position in society. One more feature of this region is the traditional cult of elders and an institution of mother-in-law. In this regard, young females, and especially daughters-in-law, take increasingly dependent positions. Young employed women usually are not allowed to manage their salary and cannot decide during family budget distribution. At the same time, by introducing certain social stereotypes to the consciousness of people, local communities of the region are capable not only to assist with solving some social and domestic problems but also to revive and cultivate the burdensome traditional ritualism as well as resurrect the prejudices and discrimination against women existing in the society. ${ }^{36}$

In several states of the region, especially in rural areas, a tradition of bride kidnapping persists, when females are kidnapped and given in marriage against their will. ${ }^{37}$ It is important to note that this tradition is not related to traditional sharia norms at all. The burdensome ritualism persists, manifesting itself in arranged marriages, the price of the bride, etc. There are cases of suicides among

35 А. Яйлымова, Один шаг вперед, два шага назад: 25 лет прав женщин Туркменистана [One step forward, two steps back: 25 years of women's rights in Turkmenistan], in М. Ларюэль, А. Курманова (ред.), Центральная Азия - 25: Мысли о прошлом, проекция будущего. Сборник эссе из Центральной Азии, Вашингтон, 2017, с. 57.

${ }^{36}$ R. Zharkynbayeva, A. Abdiraiymova, K. Santaeva, K. Smagulov, New Independent States of Central Asia: Mobilization Experience of Local Communities, in "Codrul Cosminului", 2019, Vol. 25, Issue 1, pp. 159-180.

${ }^{37}$ Е. Ларина, О. Наумова, “Кража невест - это вечный наш обычай: умыкание невесты у российских казахов" ["Bride kidnapping is our perpetual custom: kidnapping of brides by Russian kazakhs”], “Среднеазиатские исследования. Этнографическое обозрение”, 2010, No. 5, сс. 3-20. 
young women living in the region; some are closely tied to the bride kidnapping tradition. For instance, 270 self-immolation cases were reported in Uzbekistan between 1986 and 1987, and 13 self-immolation cases in the five months of 1989 in the Samarkand region. ${ }^{38}$

At the same time, some supporters of traditionalism in mass media allow themselves to express their offensive judgments: "Women manipulate men in other ways, and to express their anger, they choose another method: they attempt suicide... that is why death is the result of such attempts is 3-4 times less than the attempts committed by men. Out of 10 attempts, only 1 has a fatal result."39

According to Akhmedova, the most significant number of suicides among Uzbek women are committed in rural areas. One ethnopsychological feature is expressed in suicides by self-immolation. Self-immolation has a strong emotional impact on witnesses. At the same time, it allows emphasizing "self-sacrifice" and a demonstrative way of passing. This author states that the relatively low cultural level of relationship between spouses and the legacy of patriarchal-feudal traditions is an impetus for the suicide of young Uzbek women. ${ }^{40}$

Moreover, sociological research conducted during the end of 1980s and beginning of 1990s and 2000s illustrated self-immolation as the most common way of committing suicide. In line with this, the Republican Burn Center's statistics reported 48 patients with self-immolation diagnosis in 2003, 73 people in 2004, 63 people in 2005, and 7 in 2 months of 2006. As Hushkadamova notes, women attempted to attract attention to their numerous problems by these acts of suicide. The reasons are diverse: an unrequited love, prohibition of education, a conflict with husband's family, extramarital affairs, conflict with management at work, domestic violence, etc. ${ }^{41}$

It is also worth noting that increasing education levels among women would contribute to the higher woman's status in the family and the achievement of gender equality. There is a strong correlation between a woman's level of education and the probability of tolerating domestic violence. The higher woman's education level, the less likely she would accept domestic violence. Generalizing this

38 Д. А. Алимова, Женский вопрос в Средней Азии. История изучения и современные проблемы [Women's question in Central Asia. History of studying and modern problems], Ташкент, 1991. с. 120.

${ }^{39}$ М. Тохтаходжаева, Утомленные прошлым..., с. 28.

${ }^{40}$ Ibid.

41 O. Х. Хушкадамова, Самосожжение женщин как социальное явление [Women's selfimmolation as social phenomena], “Социологические исследования”, 2008, No. 5, сc. 125-134. 
tendency and representing the consecutive direct effect of this relationship, it should be emphasized that to increase the level of education in Tajikistan could significantly change women's status in the family. ${ }^{42}$

The report on women's status in Uzbekistan (1999) states that cases of forced early marriages and prohibition to work outside the house violate women's rights. The report also provides examples of discrimination. Family tensions concerning parents' intolerance of their daughter's opinions and commitment caused the young woman to commit suicide by jumping out the window of a building with nine floors. In another case, a girl died from severe stab wounds. She stabbed herself because her parents did not allow her to cut her hair. Sometimes young women are forced into marriage, which is harmful to health, especially mental health, particularly in early and unwanted pregnancies. 43

These facts of women's rights violation characterize all states of the region to varying degrees. Re-traditionalization and archaization of social life contribute to the reanimation of discriminating traditions (violent bride-kidnapping, arranged marriages, wearing a hijab, and polygamy). According to Kyrgyz researchers, a significant part of the society, especially Muslims, considers the traditions mentioned above to be indigenous and do not perceive them as discriminating. Even though these traditions are not supported at the governmental level, they persist and are passed across generations. ${ }^{4}$

The relationship between men and women are influenced by culture, traditions and a variety of other factors. Cultural heritage is valuable for each nation; nevertheless, it should not be used as a tool for restricting society's freedoms and rights.

\section{POLITICAL REPRESENTATION}

Independence announced in 1991 did not really influence attempts to

\footnotetext{
42 Норико Игараси, Казухиро Кумо, Голоса женщин ..., p. 84.

43 Женщины в Республике Узбекистан. Краткий информационный доклад [Women in the Republic of Uzbekistan. Short informational report], Азиатский Банк Развития, 2001, c. 23, in https://www.adb.org/sites/default/files/institutional-document/ 149311/women-uzbekistan-ru.pdf (Accessed on March 1st, 2020)

${ }^{44}$ Б. Г. Тугельбаева, А. Д. Хамзаева, С. Д. Хамзаева, Исторические предпосылки и современные причины сохранения дискриминирующих женщин обычаев в Кыргызстане [Historical premises and modern reasons for preservation of customs which discriminate women in Kyrgyzstan], "Вопросы российского и международного права", 2018, Vol. 8, No. 1A, cc. 7-15.
} 
achieve gender equality in the political sphere. Discontinuation of the quota system for political representation caused a significant reduction of woman's eligibility for local and republican levels.

The changes can be observed through the following statistics of women eligibility changes in the Parliament of the Republic of Kazakhstan. During the first convening of the Parliament (1996-1999) there were 67 deputies, but only nine were women. During the second (1999-2004) and the third (2004-2007) convening of the Parliament, women deputies were 8 out of 77 deputies. During the fourth (2007-2011) and the fifth (2012-2015), there were 107 deputies or more specific 17 and 26 women deputies. During the sixth convening (2016-present) out of 107 deputies, there were 78 men (73\%) and 29 women (27\%). ${ }^{45}$

The dynamics of woman's eligibility in the Parliament of the Kyrgyz Republic by percentages are as follows: $3.6 \%$ during the first convening of the Parliament (1995-2000), 6.7\% during the second convening (2000-2005), 0\% during the third (2005-2007), 25,5\% during the fourth (2007-2010), and 21\% during the fifth convening of the Parliament (2010-2015). On 1st January 2018, only $16,7 \%$ of deputies were women (20 out of 120).46

In Turkmenistan, Turkmenistan Women's Union was created in order to increase the participation of women in social, production and cultural life. During the first five meetings of the Parliament of Turkmenistan, there were no Union representatives among deputies. Only during the sixth convening (2013-2018), 16 representatives of the Union were deputies out of 125.47 It is also worth noting that, since 2000, the Women's Union's Central Council's Chair has been elected as the Chairman of the National Trade Union Centre of Turkmenistan.

Regarding the Parliament of the Republic of Uzbekistan, during 2010 there were 33 women deputies, which makes $22 \%$. At the same time, the representative

45 История развития парламентаризма в Казахстане [The history of the development of the Parliamentarism in Kazakhstan], http://www.parlam.kz/ru/history (Accessed on March 1st, 2020)

46 Женщины и мужчины Кыргызской Республики, 2013-2017 [Women and men of the Kyrgyz Republic, 2013-2017], Бишкек, 2018, с. 36, http://www.stat.kg/media/ publicationarchive/20232a59-bc04-4b2f-b8da-5220d4afbecc.pdf (Accessed on March 1 $\left.1^{\text {st }}, 2020\right)$

47 Союз женщин Туркменистана [Union of Turkmen Women], https://ru.wikipedia.org/wiki/\%D0\%A1\%D0\%BE\%D1\%8E\%D0\%B7_\%D0\%B6\%D0\%B5\%D0\%BD\% D1\%89\%D0\%B8\%D0\%BD_\%D0\%A2\%D1\%83\%D1\%80\%D0\%BA\%D0\%BC\%D0\%B 5\%D0\%BD\%D0\%B8\%D1\%81\%D1\%82\%D0\%B0\%D0\%BD\%D0\%B0 
bodies of the regions consisted of $15 \%$ of women deputies. ${ }^{48}$ In 2014, 24 out of 150 elected deputies were women (16\%).49

Women political participation in Tajikistan is also low. For instance, in 2015 only $19 \%$ were deputies of the Parliament. 50

Several factors can explain this tendency for women underrepresentation. First is the removal of the quota after the collapse of the USSR. ${ }^{51}$ Even if the percentages were reintroduced in the independent republics, the numbers have not changed significantly, as evident from the above. The second factor is the so-called "double burden" 52 , which implies that women are responsible for the domestic sphere and have their employment duty. Here, it is complicated for women to take additional burden of political activity. Also, politics is considered part of the realms of men, thus discouraging the participation of women. ${ }^{33}$ When it comes to women's participation in political activities, the argument is: "women should return to the home." 54 This attitude is a consequence of attributing women to private, home space. It is worth noting that the number of seats in the Parliament, that women take does not reflect the real degree of women's political participation.

\section{OCCUPATIONAL GENDER SEGREGATION}

The occupational gender segregation defines economic opportunities of men and women by the most part. During the USSR regime, about $40 \%$ of women were employed in highly feminized sectors of the economy, such as banking and insurance (90\%), healthcare and social welfare (83\%), information and accounting (82\%), commerce (80\%), education (79\%) and culture (75\%). Only $30 \%$ worked in

48 Гендерная оценка по Узбекистану [Gender evaluation of Uzbekistan], Азиатский Банк Развития, 2014, с. 98

49 ЦИК: По итогам выборов в нижнюю палату парламента Узбекистана избраны 150 депутатов [CEC: As a result of elections 150 deputies were chosen for the Lower House of Parliament of Uzbekistan], https://uzreport.news/politics/tsik-po-itogamvyiborov-v-nizhnyuyu-palatu-parlamenta-uzbekistana-izbranyi-150-deputatov (Accessed on March 1st, 2020)

50 Страновая гендерная оценка: Таджикистан [Gender evaluation of the country: Таjikistan], Азиатский Банк Развития, 2014, с. 123

${ }^{51}$ Armine Ishkanian, Gendered Transitions: The Impact of the Post-Soviet Transition on Women in Central Asia and the Caucasus, in "Perspectives on Global Development and Technology", 2003, Vol. 2, No. 3, pp. 475-496.

52 Ibid.

53 Ibid.

${ }^{54}$ Mary Buckley, op. cit. 
the industrial sector. Women wage level constituted, on average, two-thirds of men's wage level. 55 The reforming of an economy led to a considerable decrease in the labour market's women participation rate. As growing poverty, weakened welfare, and social support affected society as a whole, women's impact was higher due to the reproductive role, family responsibilities, and strengthening traditionalism.

There is a common feature of the CA countries present regarding occupational gender segregation. Women represented more than $70 \%$ of employment in the spheres, which have traditionally been perceived as "women's occupations": education, healthcare and social sphere. Another domain, service sector, is also represented by the high percentage of women. Men dominate in the manufacturing sector, extractive industries, transport and construction industries, electricity, gas and water supply sectors, recycling. Men dominating industries are usually considered more profitable with a higher salary level..$^{56}$

The right to equal remuneration for work of equal value is a part of the International Labour Organization ideology. However, in the region, the average women's salary is lower than men's salary. For instance, the women to men's wage ratio in Kyrgyzstan in \% is as follows: $71,1 \%$ in $2014,75,5 \%$ in $2015,75,3 \%$ in 2016, 72,5\% in 2017 and $71,6 \%$ in 2018.57

UN statistics present a similar trend in other CA countries. The women to men's wage ratios in 2005 were 0.63 in Turkmenistan, 0.66 in Uzbekistan, 0.62 in Tajikistan. ${ }^{58}$ Evaluation of an income ratio of men and women's main activities, according to OECD Gender, Institutions and Development database, provided following numbers: $58 \$$ in Tajikistan, $60 \%$ in Uzbekistan, $64 \%$ in Turkmenistan. .9 The situation in Kazakhstan is quite similar. The women to men's wage ratio was

55 Программа развития ООН, Региональное Бюро по Странам Европы и СНГ, Нищета переходного периода [Poverty of the transitional period], Нью-Йорк, 1998, 248 с.

56 Р. С. Жаркынбаева, К вопросу о гендерной профессиональной сегрегации в постсоветской Центральной Азии [About the question of gender occupational segregation in post-Soviet Central Asia], in "Primo aspectu", 2016, No. 2 (26), cc. 16-29.

57 Отношение заработной платы женщин к заработной плате мужчин [The ratio of women's wage to men's wage], http://www.stat.kg/ru/opendata/category/332/ (Accessed on March 7th 2020).

58 Доклад о развитии человека 2005. Международное сотрудничество на перепутье: помощь, торговля и безопасность в мире неравенства [Human Development Report 2005: International Cooperation at a Crossroads - Aid, Trade and Security in an Unequal World], Москва, Издательство “Весь мир”, 2005, с. 325.

59 The Political and Economic Status of Women, 2009, http://stats.oecd.org/Index.aspx?DatasetCode=GID\&lang=en\# (Accessed on March 7th 2020$)$. 
$67.8 \%$ in $2013,67.0 \%$ in $2014,65.9 \%$ in $2015,68.6 \%$ in 2016 and $67.8 \%$ in 2017.60 It is worth noting that Kazakhstan is considered to have the greatest ratio of the unexplained difference in wage level in the region, which implies an assumption about the persistence of gender inequality. ${ }^{61}$

There are several reasons for the underrepresentation of women in more profitable jobs. The public sector is perceived as more flexible from the standpoint of a combination of professional and family responsibilities. Gender stereotypes also play a significant part, so that a small number of females get technical education. In addition, the CA region countries' feature is a list of occupations prohibited for females (see Appendix A). Women's rights advocates call for the abolition of the list. Therefore, there is gender, occupational segregation in the region, expressed in a significant difference in the wage level and the list of occupations prohibited for women, which are discriminatory norms.

\section{EDUCATION}

The soviet education system stressed the importance of equality between men and women in education. Despite the proclamation of the equal access of women to formal education in post-Soviet countries, gender inequality in education is still an important issue.

After the proclamation of independence, impoverishment and increasing gender inequality, they have significantly affected the declining the women's enrollment rates in secondary schools. This trend is especially noticeable in Uzbekistan, Tajikistan and partly in Kyrgyzstan. Often in rural areas, young girls have induced too early marriages or to drop out of schools because of the housework. For example, the majority of girls in Tajikistan left school before the 9th grade. This situation provoked the Tajik Ministry of Education to conduct research on two schools in Dushanbe, one school in Hisor and another in Vakhdat district. The study concluded that girls quit school due to three main reasons: poverty, priorities of family expenses and gender socialization. ${ }^{62}$

60 Женщины и мужчины Казахстана: 2013-2017 [Women and men of Kazakhstan: 20132017], Астана, 2018, с. 140.

61 Азиатский банк развития, Республика Казахстан. Гендерная оценка по стране [The

Republic of Kazakhstan. Gender evaluation of the country]. Азиатский Банк Развития, 2013, 71 с.

62 Доклад о человеческом развитии в Центральной Азии. В будущее без барьеров: Региональное сотрудничество в области человеческого развития и обеспечения человеческой безопасности [A future without obstacles: Regional cooperation in the 
There is a downward trend in the number of women acquiring education in Tajikistan since 1991, even though legislation provided necessary women's rights. Comparison of the Republic of Tajikistan's statistical data with an indicator in other Central Asian countries reveals that enrolment in secondary education of Tajik girls is less than that of Kazakhstan and Kyrgyzstan, especially in 10th and 11th grades. An opportunity to obtain an education in lyceums, gymnasiums, schools with intensive studying of different subjects is available to less than $10 \%$ of children and adolescents. The educational institutions are concentrated in urban areas, and girls' enrollment is about 1,5-2 times less than that of boys. ${ }^{63}$

Considering the 2016-2017 academic year, the enrollment in primary school (1-4 grades) is relatively high for both genders, and girls constitute about $48,3 \%$ of students. In secondary school, the number of girls represents a declining trend constituting $46.4 \%$ of students. ${ }^{64}$

In Uzbekistan, there is no difference between boys and girls in access to education in primary and secondary schools. At the same time, women's share is declining in high school (10-11 grades), vocational colleges and higher education institutions. Early marriages explain such a tendency by the most part, and gender stereotypes, especially in rural areas, which impedes an opportunity to obtain full education. ${ }^{65}$

In Kyrgyzstan, the enrollment in secondary education (10-11 grades) shows a downward trend. Here, the enrollment of girls is decreasing more rapidly than that of boys. For instance, from 2008 to 2012, registration of men in 10-11 grades decreased from $56.1 \%$ to $48.8 \%$, while for women from $65.3 \%$ to $55.6 \%$. The factors that affect the situation are early marriages and early motherhood: more than $12 \%$ of girls in Kyrgyzstan are getting married before they reach $18 .{ }^{66}$ In this way,

sphere of human development and security], Братислава, 2005, с. 181, https://www.un.org/ru/development/hdr/central_asia_2005.pdf (Accessed on March 10 ${ }^{\text {th }}, 2020$ ).

63 Национальная стратегия развития образования Республики Таджикистан до

2020 года [The national strategy of the development of education of the Republic of

Tajikistan till the year 2020], c. 13, in https://www.ilo.org/dyn/youthpol/en/ equest.fileutils.dochandle?p_uploaded_file_id =511 (Accessed on March 10 th, 2020 ).

64 Образование в Республике Таджикистан. Агентство по статистике при Прези-

денте Республики Таджикистан [Statistical agency under the President of the Republic of Tajikistan], Душанбе, 2017, с. 29.

65 Образование в Узбекистане: баланс спроса и предложения-2007 [Education in Uz-

bekistan: Equilibrium of the demand and supply-2007], Ташкент, 2007, 204 c.

66 Женщины и мужчины Кыргызской Республики: 2013-2017, Бишкек, Национальный 
low-income families and families that are living in rural areas prioritize education for men.

The higher education system of Central Asia holds a special place in the issue of sustainable development. The governments of the region have reformed the higher education system significantly over the last 28 years. Turkmen and Uzbek governments continue to monopolize the education sphere, and the government ideology has a substantial impact on education programs and scientific freedom. In contrast, Kazakhstan and Kyrgyzstan made institutional changes regarding decentralization of higher education over the last years, stimulating the development of private education and scientific freedom. The number of people enrolled in higher education institutions increased two times, and in Kyrgyzstan - 2.5 times from 1991 to 2002, while in Turkmenistan and Uzbekistan the number of students decreased by 3.7 and 1.9 times respectively. ${ }^{67}$

However, Kazakhstan and Kyrgyzstan have issues with gender imbalance in different specializations. High level of women's representation among students is mostly due to the high concentration of them in "traditionally specializations": education, journalism and information, humanities, service sector. For example, in Kazakhstan at the beginning of the 2017 /2018 academic year, women's representation by groups of specialists is as follows: education $-72.3 \%$, humanities and art $-62.7 \%$, social sciences, journalism and information $-79.6 \%$, healthcare and social wellness - $63 \% .{ }^{68}$ The trend was similar in Kyrgyzstan at the beginning of the 2017-2018 academic year. Here, women's representation by groups of specialization was as follows: humanities - $76.8 \%$, education - $86.6 \%$, journalism and information - 79,8\%, service sector - $66.6 \% .69$

In Uzbekistan, Tajikistan and Turkmenistan gender imbalance in the educational sphere is increasing.

According to official data, enrollment in higher education in the Republic of Tajikistan in 2015 was relatively low - only $18 \%$ of the whole population of the corresponding ages, which is 2.5 times lower than in developing European countries and other Central Asian countries. ${ }^{70}$ Since 1997, the President of Tajikistan

статистический комитет Кыргызской Республики, 2018, с. 99, in http://www.stat.kg/media/publicationarchive/20232a59-bc04-4b2f-b8da-

$5220 \mathrm{~d} 4$ afbecc.pdf (Accessed on March 1st, 2020).

67 Доклад о человеческом развитии в Центральной Азии. В будущее без барьеров..., с. 173.

68 Женщины и мужчины Казахстана: 2013-2017, с. 72.

69 Женщины и мужчины Кыргызской Республики: 2013-2017..., с. 97.

${ }^{70}$ Национальный обзор Республики Таджикистан по осуществлению Пекинской декларации и Платформы действий (1995 года) ... в 2015 году [National overview of 
has introduced a quota for higher education for women from rural areas. In 2006, the percentage was changed so that it covers talented men from rural areas as well. From 2010 through 2013, within the framework of State programs, a series of activities were carried out to encourage women's education. Stipends and other forms of financial aid were introduced to stimulate women to obtain an education..$^{71}$ The number of women students decreased over the ten years (1991-1992 - 2002-2003 academic years) from 34\% to $25 \% .^{72}$ However, there is an increase in women's ratio in higher education institutions, from $25 \%$ in the $2002-2003$ academic year to $29 \%$ in 2010-2011. In the next two years, there was a decline to $28 \%$, and then the ratio of women slowly increased to 35\% in the 2016-2017 academic year. ${ }^{73}$ Therefore, despite the efforts, only in the 2016-2017 academic year, women students' ratio reached the 1991-1992 academic year level - 35\%.

According to the World Bank, the general enrollment in higher education institutions of Uzbekistan decreased from 17\% to 9\% between 1991 and 2011, and remained the lowest for the regional and international standards. Kazakhstan and Kyrgyzstan's degree enrollment was $40 \%$ and $49 \%$ respectively. At the levels of primary and secondary education in Uzbekistan, the enrollment of the schoolage population is close to $100 \%{ }^{74}$

At the same time, for higher education, women have fewer opportunities than men. For example, the ratio of women among students constituted $40 \%$ in 2007. Possible reasons for families not to allow girls to study are remoteness of higher education institutions, usual for Muslim families wish not to allow women

the Tajik Republic of the implementation of the Beijing declaration and Platform for Action (1995) ... in 2015], c. 8, in https://sustainabledevelopment.un.org/content/ documents/13205Tajikistan_review_Beijing20.pdf (Accessed on March 15th, 2020).

${ }^{71}$ Национальная стратегия развития образования Республики Таджикистан..., с. 8.

72 А. Куватова, А. Байзаев, Национальный отчет о реформах в системе высшего образования и состоянии гендерного образования в Республике Таджикистан [National report about reforms of the system of higher education and status of gender education if Tajik Republic], Душанбе, 2005, c.5, in https://studylib.ru/doc/ 3995050/nacional._nyj-otchet-o-reformah-v-sisteme-vysshego (Accessed on March $\left.15^{\text {th }}, 2020\right)$.

73 Высшие учебные заведения, 1991-2017 [Higher education institutions, 1991-2017], https://www.stat.tj/ru/database-socio-demographic-sector (Accessed on March 15 ${ }^{\text {th }}$, 2020).

74 Узбекистан. Модернизация системы высшего образования [Uzbekistan. Modernization of the higher education system], Июнь, 2014, с. 16, in http://pubdocs.worldbank.org/en/695391484721687603/Uzbekistan-Higher-Education-Report-2014-ru.pdf (Accessed on March 15 th 2020 ). 
to leave their house, marriage before finishing the educational institution, inability or reluctance of families to provide opportunities for daughter's education and lack of motivation among families with low and middle income to invest in daughter's education. ${ }^{75}$ The situation did not change over the five years, as in 2011, the ratio of female students studying in Uzbek higher education institutions was only $39 \% .{ }^{76}$ Nick Megoran provides a case study of Ferghana University and states that the University space offers more freedom and opportunities to learn behavioural patterns different from those adopted at home. ${ }^{77}$ As the author found out, these have different effects on Uzbek girls. Some of them could persuade their parents to study abroad, while others had no right to do so. There was a case with a girl who was forced into a marriage, not to let her go studying abroad. Although the example of a university is not representative of all students in Uzbek higher education institutions, it does provide some guidance on how traditions discourage women from obtaining higher education.

Even though primary education is available for Turkmen girls, opportunities for continuation of education are scarce. Higher education in Turkmen universities is not accessible for many women, even though the situation was different during the Soviet period. Large families prefer to invest in the education of their sons, rather than daughters. However, society started accepting as a norm, an opportunity for women to obtain higher education abroad after the family's permission, which contrasts the tradition of not allowing girls to leave home before marriage. ${ }^{78}$

There are no open data for Turkmenistan. External data provide information only regarding the situation in the year 2014. Here, the ratio of women students in higher education institutions was $38.5 \%$. The gross enrollment ratio in higher education of the whole population in 2014 was 8\%, while in 1991 it was $21.7 \% .{ }^{79}$ Therefore, the population's low enrollment ratio is a characteristic of Turkmenistan and Uzbekistan, while Kazakhstan and Kyrgyzstan have higher rates of enrollment.

75 Образование в Узбекистане: баланс спроса и предложения-2007 [Education in Uzbekistan: equilibrium of demand and supply-2007], Ташкент, 2007, с. 110.

76 Узбекистан. Модернизация системы высшего образования образования..., с. 52.

77 N. Megoran, op. cit., p. 105-108.

78 А. Яйлымова, ор. cit., с. 56.

79 Туркменистан - Учащиеся женского пола [Turkmenistan - female students], https://knoema.ru/atlas/Туркменистан/topics/Образование/Высшееобразование/Учащиеся-женского-пола (Accessed on March 15th 2020). 
Numerous international and national studies emphasize social and economic costs, related to women education deficit. Deprivation of women from getting education contributes to social isolation; the political and economic dependence of women negatively affects sustainable development in the region. Regional governments should consider every obstacle that prevents young people from getting an education and take all necessary measures to resolve them.

It is necessary to ensure gender equality at all education levels: primary, secondary, higher and graduate. Development of educational system might contribute to the empowerment of both men and women in other spheres. It is also imperative to continue working on eliminating gender stereotypes in education and resolving the gender issue of concentration in the traditional specializations. On the one hand, it is possible to reinforce non-traditional occupations' popularization among women through mass media and organize professional events to promote technical profiles among women. On the other hand, governments could develop policies to stimulate men to study pedagogical and humanities.

\section{CONCLUSION}

The peculiarity of the region is that even though the government is concerned with promoting gender equality, society strongly resists this ideology. Resolution of issues connected to inequality and the practical realization of gender policies is impossible without understanding the importance of gender equality within the CA societies.

The region's current situation can be described as a disparity of the growth of intellectual, socio-political, spiritual and creative potential of women with a low level of realization of this potential. This issue acquires particular importance in Central Asia's current context, especially in the context of re-traditionalization of social life. Re-traditionalization revives and promotes burdensome traditions, maintains existing prejudice and forms of discrimination concerning women and results in social and economic insecurity.

Despite the relatively high legal provision of the national legislature of the Central Asian countries, the mechanism that provides equal rights to men and women are not sufficient. Some legal provisions are declarative solely, what discredits the idea of equality itself. The greatest obstacle for gender equality is the lack of awareness among women regarding their rights. Another issue is the influence of existing cultural stereotypes, representing women primarily as upholders of family values. 
It is traditionally believed in the Central Asian region that the social roles of men and women are defined biologically, and form a basis for gender discrimination. On the other hand, despite the traditionalism supporters' opposition, women become more active, which provides an opportunity for higher representation in politics, business and civil society, even though to different extents than men.

Therefore, countries of the Central Asian region are on their way to achieve gender equality. Achievement of gender equality is more perceived as "normaim", the perspective aim of the movement rather than the real result. Persistent patriarchal norms and gender stereotypes in the region decelerates the achievements of equality. Increasing gender inequality in the sphere of education, an emerging digital imbalance will significantly affect the welfare of the society, economic and social development of the countries in the long run, as well as a deterrent factor for sustainable development of the region.

\section{APPENDIX A. LIST OF PROHIBITED OCCUPATIONS FOR WOMEN}

The list of prohibited occupations for women in Kazakhstan can be found by the following link: https://tengrinews.kz/zakon/pravitelstvo-respubliki-kazahstan-premer-ministr-rk/trud/id-V070004916_/

The list of prohibited occupations for women in Kyrgyzstan can be found by the following link: http://cbd.minjust.gov.kg/act/view/ru-ru/7182

There is no available information about such lists for other countries of the Central Asian region. The list of prohibited occupation for women in Uzbekistan was repealed: https://regulation.gov.uz/ru/document/3173

\section{BIBLIOGRAPHY}

1. Buckley Mary, Victims and agents: gender in post-Soviet states, in M. Buckley (ed.), Post-Soviet Women: From the Baltic to Central Asia, Cambridge, Cambridge University Press, 1997, pp. 3-16.

2. Cleuziou Juliette, Direnberger Lucia, Gender and nation in post-Soviet Central Asia: from national narratives to women's practices, in "Nationalities Papers", Vol. 44, 2006, No. 2, p. 195-206.

3. Falkingham Jane, Baskieri Angela, Gender, poverty and transition in Central Asia, in Sylvia Chant (ed.), The International Handbook of Gender and Poverty. Concepts, Research, Policy, Cheltenham - Northampton, Edward Elgar Publishing, 2010, p.184-190. 
4. Ishkanian Armine, Gendered Transitions: The Impact of the Post-Soviet Transition on Women in Central Asia and the Caucasus, in "Perspectives on Global Development and Technology", 2003, Vol. 2, No. 3, pp. 475-496.

5. Megoran Nick, Theorizing gender, ethnicity and the nation-state in Central Asia, in “Central Asian Survey", 1999, Vol. 18, No. 1, p. 99-110.

6. Political and economic status of women, in http://stats.oecd.org/Index.aspx?DatasetCode=GID\&lang=en\#

7. Reviews of National Policies for Education - Higher Education in Kazakhstan 2017, in http://www.oecd.org/about/publishing/corrigenda.htm

8. Saktaganova Zauresh, Abdrakhmanov Kymbat, Yeleukhanova Svetlana, Dosova Bibigul, Karsybayeva Zhuldyz, Tleugabylova Kair, Women's labor and everyday life in the great patriotic war years, in “Opción”, Año 36, 2020, Especial No.27, pp. 1168-1183.

9. Ubaydullaeva Rano, Krumm Reinhard (eds.), Women of independent Uzbekistan: findings of sociological survey, Center for the Study of Public Opinion "Izhtimoy Fikr", Friedrich Ebert Foundation, Tashkent, 2004.

10.Zharkynbayeva Roza, Abdiraiymova Ardak, Santaeva Kulimkoz, Smagulov Kadyrzhan, New Independent States of Central Asia: Mobilization Experience of Local Communities, in "Codrul Cosminului" 2019, Vol. 25, No.1, p.159-180.

11. Алимова Д. А., Женский вопрос в Средней Азии. История изучения и современные проблемы [The women's question in Central Asia. History of study and modern problems], Ташкент, 1991, 120 с.

12. Ахмедова Н., К проблеме самосожжения женщин [On the problem of self-immolation of women], Ташкент: ЦИОМ, 1998.

13.В Казахстане 96\% населения имеют предрассудки в отношении женщин [In Kazakhstan, $96 \%$ of the population has prejudices against women], in https://www.kz.undp.org/content/kazakhstan/ru/home/presscenter/announcements/2020/march/in-kazakhstan-96-per-cent-of-population-are-biased-againstwomen.html

14.Высшие учебные заведения [Higher education institutions], in https://www.stat.tj/ru/database-socio-demographic-sector

15. Гендерная оценка по Узбекистану [Gender Assessment for Uzbekistan], Азиатский банк развития, 2014, 98 р.

16. Доклад о развитии человека 2005. Международное сотрудничество на перепутье: помощь, торговля и безопасность в мире неравенства [Human Development Report 2005: International Cooperation at a Crossroads - Aid, Trade and Security in an Unequal World], Москва, Издательство “Весь мир”, 2005, 416 с.

17.Доклад о человеческом развитии в Центральной Азии. В будущее без барьеров: Региональное сотрудничество в области человеческого развития и обеспечения человеческой безопасности [A future without obstacles: Regional cooperation in the sphere of human development and security], Братислава, 2005, in https://www.un.org/ru/development/hdr/central_asia_2005.pdf 
18.Докладная записка секретаря ЦК ВЛКСМ О. Мишаковой секретарям ЦК ВКП(Б) Сталину И. В., Маленкову Г. М., Жданову А. А. об оживлении пережитков феодальнобайского отношения к женщине в Узбекской, Туркменской и Таджикской ССР [Memorandum by the secretary of the Komsomol Central Committee O. Mishakova to secretaries of the Central Committee of the CPSU(b) Stalin I. V., Malenkov G. M., Zhdanov A. A. about revival of remnants of the feudal-bai perception of women in Uzbek, Turkmen and Tajik SSR], The Russian State Archive of Social and Political History (RGASPI), Fund M-1., 0. 4, D. 108, f. 22-29.

19. Жаркынбаева Р.С., К вопросу о гендерной профессиональной сегрегации в постсоветской Центральной Азии [On the issue of gender occupational segregation in post-Soviet Central Asia], in "Primo aspectu", 2016, No. 2 (26), c.16-29.

20.Женщины в Республике Узбекистан. Краткий информационный доклад [Women in the Republic of Uzbekistan. Short informational report], Азиатский Банк Развития, 2001, 23 с.

21.Женщины и мужчины Казахстана 2017 [Women and Men of Kazakhstan 2017], in https://gender.stat.gov.kz/file/WomenAndMan.pdf

22. Женщины и мужчины Казахстана: 2013-2017 [Women and men of Kazakhstan: 2013-2017], Астана, 2018, 140 с.

23. Женщины и мужчины Кыргызской Республики: 2013-2017, Бишкек, Национальный статистический комитет Кыргызской Республики, 2018, 150 с. http://www.stat.kg/media/publicationarchive/20232a59-bc04-4b2f-b8da-5220d4afbecc.pdf

24.Игараси Норико, Кумо Казухиро, Голоса женщин. Гендерное исследование в Таджикистане [Women's Voices: Gender Survey in Tajikistan], in "Japanese Slavic and East European Studies", 2016, Vol. 37, pp. 63-87.

25. История развития парламентаризма в Казахстане [The history of the development of parliamentarism in Kazakhstan], in http://www.parlam.kz/ru/history

26. Кодекс Республики Казахстан О браке (супружестве) и семье [Code of the Republic of Kazakhstan On Marriage (Matrimony) and Family], in https://online.zakon.kz/m/document/?doc_id=31102748

27.Кочкунов Айдарбек, Этнические традиции киргизского народа (социокультурные аспекты и некоторые вопросы генезиса) [Ethnic traditions of the Kyrgyz people (socio-cultural aspects and some questions of genesis)], Бишкек,2013, 320 c.

28. Куватова А., Байзаев А., Национальный отчет о реформах в системе высшего образования и состоянии гендерного образования в Республике Таджикистан [National report on reforms in the higher education system and the state of gender education in the Republic of Tajikistan], Душанбе, 2005.

29. Ларина Е., Наумова О., Кража невест - это вечный наш обычай: умыкание невесты у российских казахов [Bride kidnapping is our eternal custom: bride kidnapping from Russian Kazakhs], “Среднеазиатские исследования. Этнографическое обозрение”, 2010, №5, с. 3-20. 
30. Национальная стратегия развития образования Республики Таджикистан до 2020 года [National Strategy for the Development of Education of the Republic of Tajikistan until 2020], in https://www.ilo.org/dyn/youthpol/en/equest.fileutils.dochandle?p_uploaded_file_id=511

31. Национальный обзор Республики Таджикистан по осуществлению Пекинской декларации и Платформы действий (1995 года) ... в 2015 году [National review of the Republic of Tajikistan on the implementation of the Beijing declaration and Platform for Action (1995) ... in 2015], in https://sustainabledevelopment.un.org/content/documents/13205Tajikistan_review_Beijing20.pdf

32. Обзор Кыргызской Республики в рамках выполнения Пекинской декларации и Платформы действий «Пекин + 20» [Review of the Kyrgyz Republic in the framework of the implementation of the Beijing Declaration and Platform for Action "Beijing + 20"], in http://www2.unwomen.org

33. Образование в Республике Таджикистан. Агентство по статистике при Президенте Республики Таджикистан [Education in the Republic of Tajikistan. Agency on Statistics under the President of the Republic of Tajikistan], Душанбе, 2017, 102 c.

34.Образование в Узбекистане: баланс спроса и предложения-2007 [Education in Uzbekistan: supply and demand balance 2007], ПРООН, Ташкент, 2007, 204 с.

35. Отношение заработной платы женщин к заработной плате мужчин [The ratio of women's wages to men's wages], in http://www.stat.kg/ru/opendata/category/332/

36. Программа развития ООН, Региональное Бюро по Странам Европы и СНГ, Нuщета переходного периода [Poverty of the transitional period], Нью-Йорк, 1998, 248 с.

37. Республика Казахстан. Гендерная оценка по стране [The Republic of Kazakhstan. Country Gender Assessment], Азиатский банк развития, 2013, 71 c.

38. Семейный кодекс Кыргызской республики [Family Code of the Kyrgyz Republic], in http://www.ombudsman.kg/images/files/news/2018/zakonodatelnayabaza/ semejnij-kodeks-kg.doc

39. Семейный кодекс Туркменистана [Family code of Turkmenistan], in http://www.turkmenbusiness.org/content/semeinyi-kodeks-turkmenistana

40. Семейный Кодекс Республики Таджикистан 2011 [Family Code of the Republic of Tajikistan], in http://www.afew.tj/images/files/pdf/semeynyy_kodeks_rt.pdf

41. Семейный Кодекс Республики Таджикистан [Family Code of the Republic of Tajikistan], in http://minjust.ru/sites/default/files/basetype/2011/11/5_tadzhikistan.doc

42. Семейный Кодекс Республики Узбекистан [Family Code of the Republic of Uzbekistan], in //http://www.lex.uz/acts/104723

43. Союз женщин Туркменистана [The Union of Turkmen Women], in https://ru.wikipedia.org/wiki/\%D0\%A1\%D0\%BE\%D1\%8E\%D0\%B7_\%D0\%B6\%D0\% B5\%D0\%BD\%D1\%89\%D0\%B8\%D0\%BD_\%D0\%A2\%D1\%83\%D1\%80\%D0\%BA\%D0\% BC\%D0\%B5\%D0\%BD\%D0\%B8\%D1\%81\%D1\%82\%D0\%B0\%D0\%BD\%D0\%B0 
44. Страновая гендерная оценка: Таджикистан [Country Gender Assessment: Tajikistan], Азиатский банк развития, 2014, 123 с.

45. Тохтаходжаева М., Утомленные прошлым. Реисламизация общества и положение женщин в Узбекистане [Burnt by the past. Re-Islamization of Society and the Status of Women in Uzbekistan], Ташкент, 2001. 352 c.

46. Тугельбаева Б. Г., Хамзаева А. Д., Хамзаева С. Д., Исторические предпосылки и современные причины сохранения дискриминирующих женщин обычаев в Кыргызстане [Historical background and modern reasons for the persistence of customs that discriminate against women in Kyrgyzstan], “Вопросы российского и международного права", 2018, Том 8, № 1А, с. 7-15.

47. Туркменистан - Учащиеся женского пола [Turkmenistan - Female students], in https://knoema.ru/atlas/Туркменистан/topics/Образование/Высшее-образование/ Учащиеся-женского-пола

48. Узбекистан. Модернизация системы высшего образования [Uzbekistan. Modernization of the higher education system], Июнь, 2014, in http://pubdocs.worldbank.org/en/695391484721687603/Uzbekistan-Higher-Education-Report2014-ru.pdf

49. Хасанова Г. А., Гендер, политика, демократия [Gender, politics, democracy], Алматы, Институт Развития Казахстана, 2002, 294 с.

50.Хушкадамова О.Х., Самосожжение женщин как социальное явление [Selfimmolation of women as a social phenomenon], in "Социологические исследования", 2008, c. $125-134$.

51.ЦИК: По итогам выборов в нижнюю палату парламента Узбекистана избраны 150 депутатов [CEC: As a result of elections 150 deputies were chosen for the Lower House of Parliament of Uzbekistan], in https://uzreport.news/politics/tsik-po-itogam-vyiborov-v-nizhnyuyu-palatu-parlamenta-uzbekistana-izbranyi-150-deputatov

52. Эргашева М., Время расцвета: деловая активность женщин как одна из составных частей дальнейшего развития Узбекистана [The heyday: the business activity of women as one of the components of the further development of Uzbekistan], Ташкент, Издательство Национальной библиотеки Узбекистана им. А. Навои, 2004, 168 с.

53. Яйлымова А., Один шаг вперед, два шага назад: 25 лет прав женщин Туркменистана [One step forward, two steps back: 25 years of women's rights in Turkmenistan], in М. Ларюэль, А. Курманова (ред.), Центральная Азия - 25: Мысли о прошлом, проекция будущего. Сборник эссе из Центральной Азии, Вашингтон, 2017, с. 55-58. 